\title{
LAST DEGLACIATION OF NORTHERN CONTINENTAL EUROPE
}

\section{MARKS}

\author{
Faculty of Geology, University of Warsaw, Żwirki i Wigury 93, 02-089 Warsaw, Poland. \\ Polish Geological Institute - National Research Institute, Rakowiecka 4, 02-089 Warsaw, Poland.
}

\begin{abstract}
Correlation of main ice sheet limits in northern continental Europe during Late Weichselian is presented, based on available data concerning occurrence of ice-marginal formations and their radiometric dating. The Late Weichselian maximum ice sheet limit was time-transgressive in this region what has been primarily caused by diversified dynamics of the ice sheet body, composed of several paleo-ice streams developed to the south of the Baltic Basin. The Late Weichselian maximum ice sheet limit was the earliest in Denmark, Germany and western Poland (24-22 cal kyrs BP) but it was younger to the east and northeast (20-17 cal kyrs BP). Such age difference resulted from demarcation of the ice sheet maximum limit by successive glacial advances. They were partly due to varied distances from the ice divide in Scandinavia, making the ice sheet margin to reach its terminal position in different time. Both during the maximum and the most deglacial phases the glacial limits indicated lobate patterns of marginal formations, reflecting outlets of paleo-ice streams within the southern and southeastern fringe of the Scandinavian Ice Sheet to the south of the Baltic Sea basin. During deglaciation numerous readvances and standstills of the ice sheet margin occurred but due to diversified structure of the ice sheet body, its peripheries behaved differently, even in neighboring regions.
\end{abstract}

\section{La última deglaciación en la Europa continental septentrional}

RESUMEN. Se presenta la correlación de los principales límites del inlandsis en la Europa continental septentrional durante el final del Weichseliense, a partir de los datos disponibles sobre la formación de masas de hielo marginales y su datación radiométrica. La máxima extensión de finales del Weichseliense fue transgresiva en esta región, debido a la diversa dinámica de la masa de hielo, compuesta por varios cursos de hielo desarrollados hacia el sur de la cuenca Báltica. El límite máximo del hielo se alcanzó primero en Dinamarca, Alemania y Polonia Occidental (24-22 cal ka BP), pero fue más reciente hacia el este y nordeste (20-27 cal ka BP. Esta diferencia de edad fue el resultado del límite máximo alcanzado por el inlandsis en sucesivos avances glaciares. Eso fue debido en parte a las distintas distancias desde la divisoria de hielo 
en Escandinavia, haciendo que la posición terminal del frente del inlandsis se alcanzase en momentos diferentes. Tanto durante el máximo como durante las fases de deglaciación, los límites glaciares presentaron patrones lobulados correspondientes a formaciones marginales, y reflejando la salida de paleo-cursos de hielo en el borde meridional y sudoriental del inlandsis escandinavo hacia el mar Báltico. Durante la deglaciación ocurrieron numerosos reavances y detenciones del frente de hielo, pero debido a la diversificada estructura de la masa de hielo, su periferia se comportó de manera muy diferente, incluso en regiones próximas.

Key words: Pleistocene, Weichselian, Scandinavian ice sheet limits, ice-marginal formations, deglaciation.

Palabras clave: Pleistoceno, Weichseliense, límite del inlandsis escandinavo, formaciones marginales de hielo, deglaciación.

Received 18 December 2014 Accepted 1 March 2015

*Corresponding author: Faculty of Geology, University of Warsaw, Żwirki i Wigury 93, 02-089 Warsaw, Poland; Polish Geological Institute - National Research Institute, Rakowiecka 4, 02-089 Warsaw, Poland. E-mail: leszek.marks@uw.edu.pl, leszek. marks@pgi.gov.pl

\section{Introduction}

The term 'Weichselian' was introduced for the last Scandinavian glaciation in northern continental Europe by Keilhack (1899), after the German name 'Weichsel' for the Vistula River. This term has been the most popular in Denmark and Germany, but local names have been widely used in most other European countries, among others including Vistulian in Poland, Poozerian in Belarus, Nemunas in Lithuania, Baltija in Latvia, Järva in Estonia and Valday in Russia. The Late Weichselian has been commonly improperly correlated with the Last Glacial Maximum (LGM), although the latter was conventionally defined from sea-level records and accepted as the most recent interval with maximum volume of global ice sheets (cf. Clark et al., 2009).

A history of investigations of the Late Weichselian glacial limits was initiated by Woldstedt (1925) who distinguished three main glacial phases in central Europe, in turn Brandenburg, Frankfurt and Pomeranian ones. Basing on geomorphological criteria, Lencewicz (1927) distinguished a 'great oscillation' in central Poland, at present considered for representing the maximum ice sheet limit during the last Scandinavian glaciation. Lewiński et al. (1927) and Woldstedt (1931) gave significant support to this idea. The above mentioned names of phases by Woldstedt (1925) are still widely used for correlation in most central and eastern European countries (e.g. 
Guobytè, Satkūnas, 2011; Houmark-Nielsen, 2012; Lüthgens, Böse, 2011; Marks, 2012; Velichko et al., 2011), although the primary list of glacial phases has been considerably enriched, because many other local glacial phases and ice sheet margin standstills were distinguished.

Limits of glacial phases in Europe during the Late Weichselian and during the last deglaciation have been studied for over 80 years. They were demarcated using mainly morphological and geomorphological criteria (cf. Liedke, 1981), but at first without any or with a very limited support from field data. The present contribution is a concise overview of the Late Weichselian ice sheet limits in northern continental Europe, including southwestern, southern and southeastern sectors of the Scandinavian Ice Sheet (SIS). It compiles regional data published recently (cf. Ehlers, Gibbard, 2004; Lambeck et al., 2010; Ehlers et al., 2011), collected by many authors with a use of different geomorphological and geological methods, as well as supplemented with updated chronology based mostly on interpretation of available radiocarbon, OSL and cosmogenic isotope ages. Varying accuracy of the source data makes this contribution to be a provisional state-of-art review and it should be obviously a subject to further corrections and improvement.

\section{Methods}

Most primary source material came from analyses of geological and geomorphological maps. Depending on the country, the scales of the maps were from detailed to general ones and Poland was the only exception and provided with most uniform data, because detailed geological mapping in scale 1:50,000 has been already completed for the whole territory of this country. A supplementary material that has been occasionally used in this contribution included results of till fabric analysis, varied clast petrography of tills with indicator erratics and trace elements, distribution of glacial rafts and orientation of glaciotectonic deformations. Such data were restricted to several areas only, but they enabled reconstruction of the ice-flow pattern during the Late Weichselian, although with varied accuracy in different countries. The published geological material was critically selected and compiled, resulting in the most reliable ice sheet limits in the area of northern continental Europe.

\subsection{Geomorphology}

The northern European area that was occupied by the ice sheet during the Late Weichselian is characteristic for its fresh glacial landscape. Determination of the maximum ice sheet limit has been based mostly on geomorphological criteria, supplied and corrected occasionally with results of interpretation of a digital terrain model. Glacial features were the most important, with occurrences of ice-marginal formations including end moraines and outwash plains, supplemented with streamlined glacial landforms, mostly tunnel valleys, drumlins and eskers. End moraines, proximal parts of outwash plains and distal outlets of tunnel valleys indicated straightforward a location of the ice sheet margin during readvances and standstills of the ice margin. All other glacial landforms were not so precise for this purpose and were basically used 
for rough approximation of the ice sheet extent only. They were much more useful for reconstruction of ice-flow directions and internal structure of the ice sheet body in most areas of northern continental Europe.

\subsection{Age model}

Ages of the maximum ice sheet limit and of deglacial phases in central and eastern Europe during Late Weichselian were based on radiocarbon, cosmogenic isotopes ${ }^{36} \mathrm{Cl}$ and ${ }^{10} \mathrm{Be}$, OSL and thermoluminescence dating, supplemented occasionally by 'floating' chronologies based on counting of laminas of ice-dammed lake deposits but not continued until the present (cf. Kozarski, 1995). An important input to age estimates of the Late Weichselian ice sheet limits from cosmogenic isotope dates came not only from erratics but also from surface glacial deposits in the vicinity of the sampled boulders (Dzierżek and Zreda, 2007; Rinterknecht et al., 2005, 2006a, b, 2007, 2008; cf. Marks, 2012). There were also hundreds of thermoluminescence dates from the Late Vistulian glacial sediments, the Baltic Sea Basin included (e.g. Mojski, 1992), but value of such ages has been recently seriously questioned for glacial deposits (Stankowski et al., 1999; Ber, 2002; Raukas, Stankowski, 2005) and the OSL dates have been found lately to be more reliable (e.g. Houmark-Nielsen, 2008; Lüthgens, Böse, 2011).

The ages were treated as either minimum or maximum ones for the relevant ice sheet limits. All these available ages interpreted together provided a rough chronology of the Late Weichselian ice sheet limits in a regional and inter-regional context. The radiocarbon ages were adjusted to a calendar year scale by reference to a calibration curve (Reimer et al., 2009) and were described as 'cal yrs BP'. All other ages were commonly treated as real ('calendar') ones but to make a distinction from radiocarbondefined ages, their numerical values were accompanied by 'ka BP'.

\section{Regional overview}

Ice sheet limits of the last deglaciation are presented for each country, starting from Denmark in the west, through Germany, Poland, Belarus, Lithuania, Latvia and Estonia to northwestern Russia in the north-east (Fig. 1). The idea of this contribution was to make correlation of ice sheet limits in a continental scale, basing on detailed description and presentation in the cited references. Accuracy of recognition and chronology of the Late Weichselian deglacial phases were considerably varied and it complicated final correlation (Table 1). Therefore, the presented compilation should be treated with caution, especially due to diversified stream-like structure of the ice sheet body (cf. Kliewe, 1961; Punkari, 1997; Marks, 2002, 2004; Boulton et al., 2004) that made the suggested correlation of glacial phases in different regions to be occasionally in contradiction to the available scarce numerical ages. 


\begin{tabular}{|c|c|c|c|c|c|c|c|c|c|c|}
\hline 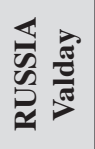 & & $\frac{\pi}{3}$ & & & $\underset{50}{500}$ & $\begin{array}{l}\frac{\pi}{N} \\
0 \\
0 \\
0 \\
\omega\end{array}$ & $\begin{array}{l}\frac{.0}{0} \\
\frac{2}{2} \\
\frac{0}{2}\end{array}$ & $\begin{array}{l}\vec{a} \\
\frac{y}{1} \\
\frac{5}{0} \\
\frac{\pi}{0} \\
0\end{array}$ & & \\
\hline 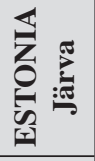 & : & 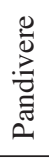 & & & 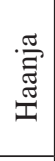 & & & & & \\
\hline 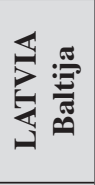 & & & 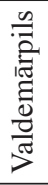 & 胥 & $\begin{array}{c}\stackrel{\Xi}{0} \\
\stackrel{0}{\Xi}\end{array}$ & 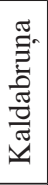 & 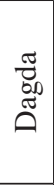 & & & \\
\hline 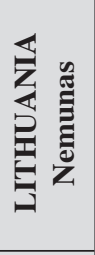 & & & & 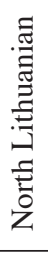 & 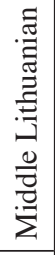 & 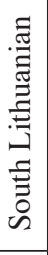 & 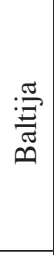 & $\sum_{0}^{\frac{\pi}{2}}$ & & \\
\hline 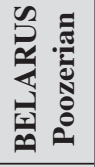 & & & & & & & 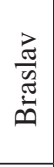 & $\begin{array}{l}\frac{\pi}{5} \\
\frac{5}{0}\end{array}$ & & \\
\hline 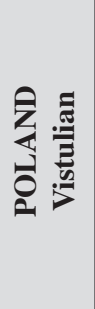 & & & & 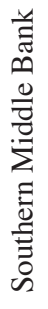 & 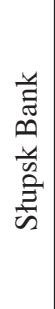 & 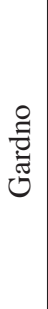 & 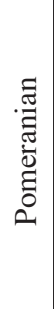 & $\begin{array}{l}\text { :ี } \\
\text { స̃ } \\
\text { م }\end{array}$ & & 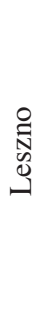 \\
\hline 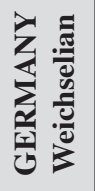 & & & & & & 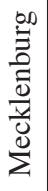 & 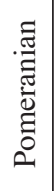 & 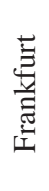 & & 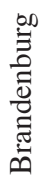 \\
\hline 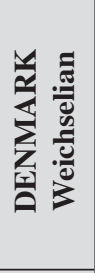 & & & & & & $\sum_{\Sigma}^{\bar{Q}}$ & 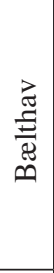 & 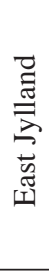 & 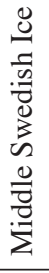 & $\stackrel{\Xi}{\Xi}$ \\
\hline 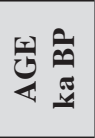 & $\hat{\mathrm{I}}$ & $\stackrel{n}{n}$ & \pm & $\begin{array}{l}m \\
\stackrel{m}{7} \\
\stackrel{1}{+} \\
\dot{J}\end{array}$ & $\begin{array}{l}n \\
m \\
\frac{n}{1} \\
\dot{\Xi} \\
\dot{\Xi}\end{array}$ & 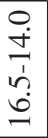 & $\frac{I}{ \pm}$ & $\frac{\infty}{\grave{1}}$ & $\tilde{\vartheta}$ & $\begin{array}{l}\vec{\sim} \\
\dot{\sim}\end{array}$ \\
\hline
\end{tabular}




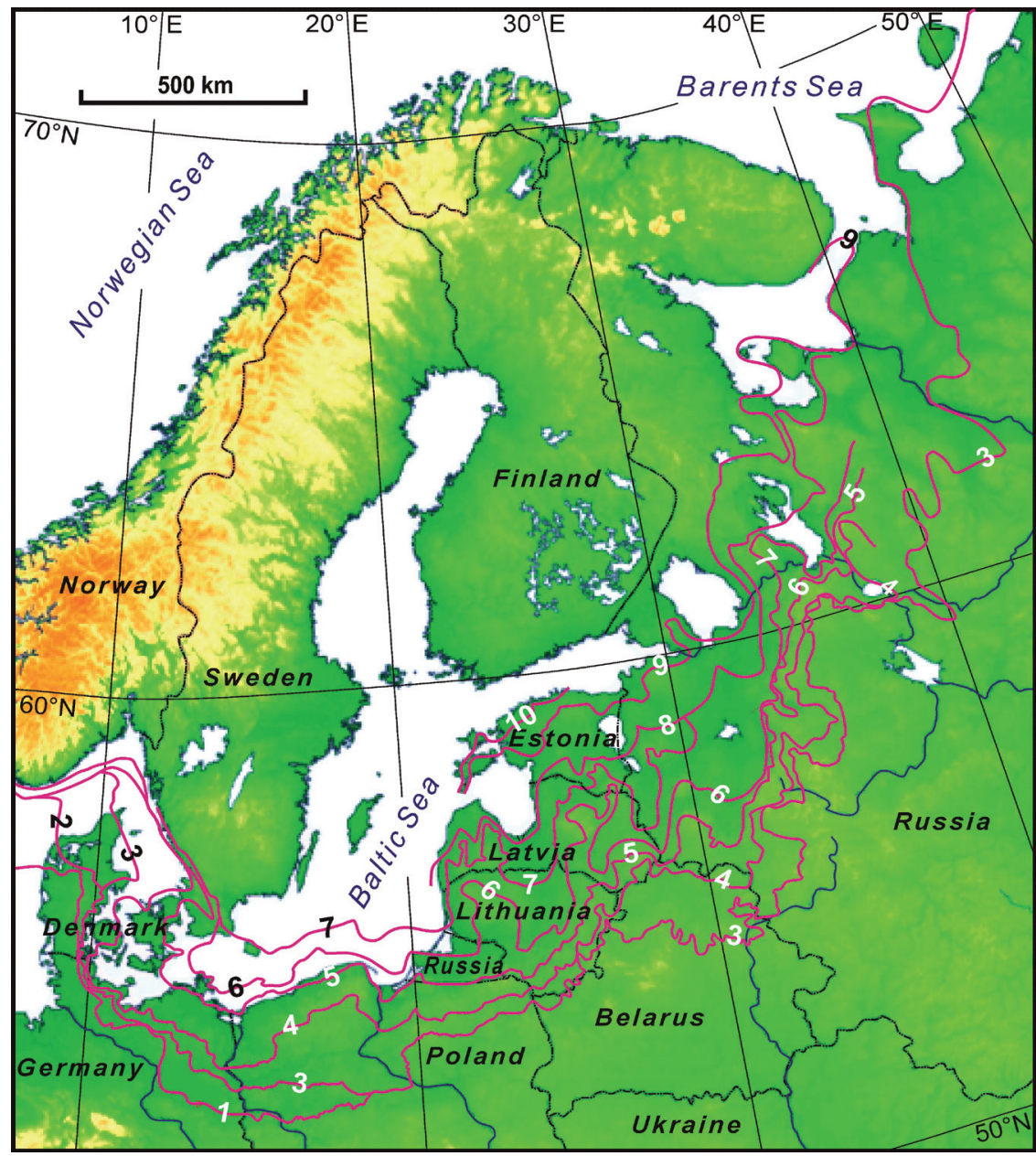

Figure 1. Location sketch of northern continental Europe with Late Weichselian limits of major glacial phases of Scandinavian and Barents ice sheets (cf. Table 1): 1-Main, Brandenburg and Leszno, 2 - readvance of the Norwegian Channel Ice Stream, 3 - East Jylland, Frankfurt,

Poznan, Orsha, Grūda and Ostashkov, and also Barents Ice Sheet maximum limit in the very north-east, 4-Balthav, Pomeranian, Braslav, Baltija, Dagda and Vepsian, 5 - Møn, Mecklenburg, Gardno, South Lithuanian, Kaldabruna and Sebezha, 6 - Stupsk Bank, Middle Lithuanian, Gulbene, Haanja and Luga, 7 - Southern Middle Bank, North Lithuanian, Linkuva and Otepä̈̈, 8 -Valdemārpils and Sakala, 9 - Pandivere and Neva, 10 - Palivere.

\subsection{Denmark}

The SIS came to Denmark from the northeast during the Main advance that crossed the Kattegat area and reached the Main Stationary Line (Fig. 1) around 20-22 ka BP (Houmark-Nielsen, 2012). Location of the ice sheet margin was indicated by numerous proximal outwash plains and by few small push moraines. This ice sheet advance was 
followed by a general retreat northeastwards, occasionally interrupted by standstills and readvances of the Norwegian Channel Ice Stream, for example at 20-19 ka BP (HoumarkNielsen, Kjær, 2003), limits of which were indicated locally by large end moraines. The following glacial episode was connected with the Young Baltic Ice that advanced from the east around 20-18 ka BP, pushing up prominent marginal moraines (HoumarkNielsen, 2011). After reaching its maximum extent during the East Jylland phase at 19-18 ka BP, the ice sheet split into several secondary ice streams during the Bælthav phase at 18-17 ka BP (Houmark-Nielsen, 2011). Downwasting of the ice sheet was interrupted by building of end moraines during the Møn phase at 17-16 ka BP (Fig. 1) that can be referred to the Halland Coast phase (17-15 ka) in Sweden (cf. Houmark-Nielsen, 2008). The following deglaciation resulted in a terminal position of the ice sheet along the eastern coast of the Bornholm Island in the western Baltic Sea (Houmark-Nielsen, 2011).

\subsection{Germany}

The Late Weichselian ice margin was strongly fragmented into lobes and the Baltic Sea depression was important in controlling ice-movement directions (Stephan, 2001). The ice sheet occupied a small present coastal area in western part of the country but further to the east it advanced over $200 \mathrm{~km}$ inland (Fig. 1). The Late Weichselian glaciation in Germany began about 25 cal kyr BP with three classical ice-marginal positions named Brandenburg, Frankfurt and Pomeranian (cf. Woldstedt, 1925), each of them subdivided into several arcs of end moraines (Ehlers et al., 2011). The Brandenburg phase at $>23 \mathrm{ka} \mathrm{BP}$ was followed by the Frankfurt phase at $18 \mathrm{ka} \mathrm{BP}$ and the Pomeranian phase at 15.8 cal kyr BP (cf. Litt et al., 2007; Heine et al., 2009; Lüthgens et al., 2010; Lüthgens, Böse, 2011). To the north, the so-called Rosenthal end moraine was distinguished and correlated with the Mecklenburg Advance (ca. 15 cal kyr BP; Rinterknecht et al., 2012). The Frankfurt Phase was an ice sheet standstill, whereas three others were readvances of the ice sheet margin (Fig. 2; Ehlers et al., 2011; Lüthgens, Böse, 2011).

\subsection{Poland}

The late Vistulian ice sheet limits in Poland were indicated by ice-marginal formations, generally with small end moraines, ice-marginal fans and outwash plains (Marks et al., 2006; Marks, 2011). The southernmost extent of the ice sheet in western Poland was connected with the Leszno phase at 24 cal kyrs BP. The next was the Poznan phase (20-19 cal kyrs BP) that was the ice margin standstill after 50-70 km retreat in western Poland but it was undoubtedly a transgressive glacial episode and indicated maximum ice sheet limit in central and eastern Poland, were a distinct lobe occurred in the Middle Vistula valley (cf. Marks, 2012). The Poznań phase was followed by ice sheet advance during the Pomeranian phase (17-16 cal kyrs BP) when several glacial lobes at the ice margin were formed. The Gardno Phase was a transgressive event, expressed by prominent push moraines in central part of the Polish seashore and it was dated at 16.816.6 cal kyrs BP. Two younger ice sheet limits were distinguished in the southern Baltic Sea Basin to the north of the present Polish coastline (Fig. 1). They were in turn the Słupsk Bank Phase, dated at 16.2-15.8 cal kyrs BP and the Southern Middle Bank Phase, 
dated at 15.4-15.0 cal kyrs BP (Uścinowicz, 1999). The former could be correlated with the Central Skåne phase (16-15 kyrs BP) in Sweden (Houmark-Nielsen, 2008). However, a scarcity of data, no exact dates and problematic correlation with the neighboring areas made their more detailed correlation very difficult (cf. Marks, 2002).

\subsection{Belarus}

Deposits of the Poozerian Glaciation have been examined both in northwestern and northern part of the country. Limits of the glacial phases during deglaciation were determined mainly on the basis of geomorphological investigation (interpretation of satellite and aerial photos included), supplemented locally with geological data (Karabanov, Matveyev, 2011). Maximum extent of the last glaciation in Belarus was based on studies of glacial landforms as well as fabrics, mineralogy and petrography of tills, supplemented with radiocarbon and cosmogenic ages that enabled its dating at 1920 cal kyrs BP in the western part of the country (cf. Marks, 2012). During deglaciation no large end moraines were formed, because areal deglaciation was predominant and resulted mostly in dead-ice topography. In the northeastern part of the country the successive two main ice sheet limits, namely Orsha and Braslav (Fig. 1), were dated at 17.7 and $13.1 \mathrm{ka} \mathrm{BP}$, respectively (Rinterknecht et al., 2007). During deglaciation several lobes in the ice sheet margin could be distinguished (cf. Kalm, 2012).

\subsection{Lithuania}

The Late Weichselian ice sheet limit (Grūda phase) was represented by end moraines in a southeastern part of the country. This phase has been correlated for a long time with the Brandenburg phase in Germany (cf. Guobyte, 2004; Guobyte, Satkūnas, 2011). However, its recent approximate dating at no earlier than 22-21 ka but presumably to $19 \mathrm{ka}$ (Bitinas, 2012), an initial retreat before $18.3 \mathrm{ka} \mathrm{BP}$ (Rinterknecht et al., 2008) and correlation with glacial phases in eastern Poland and western Belarus found it to be synchronic with the Frankfurt phase (cf. Marks, 2012; Table 1). Ice-marginal formations of the younger icemarginal formations were arranged in several lobes. The Baltija phase represented a readvance, expressed by push moraines and proglacial meltwater valleys, formed some 14.0 ka BP (Rinterknecht et al., 2008). The younger phases (Fig. 2), expressed by the South Lithuanian (ca. $13.8 \mathrm{ka} \mathrm{BP}$ ) and the Middle Lithuanian (13.5 ka BP) standstills of the ice margin, and the North Lithuanian re-advance (13.3 ka BP) were indicated by end moraines, ice-marginal fans and kame terraces (Guobyte, Satkunas, 2011).

\subsection{Latvia}

Most glacial landforms were formed during oscillatory retreat of the Late Weichselian ice sheet (Zelčs et al., 2011) and the deglacial history started with Dagda ice-marginal position, followed by Kaldabrun,a, Gulbene, Linkuva and Valdemārpils ones (Table 1). The two oldest ones were distinguished in the southeastern part of the country only (Fig. 1). There was no direct dating of the Dagda phase but in spite of that, it was usually correlated with the Baltija (Pomeranian) phase in Lithuania (cf. Fig. 2). Marginal moraines, composite glaciotectonic 
ridges and meltwater spillways represented the Kaldabruna phase but its minimum age of $15.5 \mathrm{ka} \mathrm{BP}$ was estimated by a single ${ }^{10} \mathrm{Be}$ age only (Rinterknecht et al., 2006b). These two marginal zones represented terminations of two lobes of the Peipsi Ice Stream (Zelčs et al., 2011). During the younger Gulbene phase (minimum age $13.5 \mathrm{ka} \mathrm{BP}$ ) most of eastern Latvia was ice-free and the ice sheet limit was expressed by end moraines and spillway valleys. The Linkuva terminal zone was well demarcated by end moraines whereas the ones of the Valdemārpils glacial phase were generally insignificantly small. These two last ice sheet limits have not been reliably dated in Latvia yet.

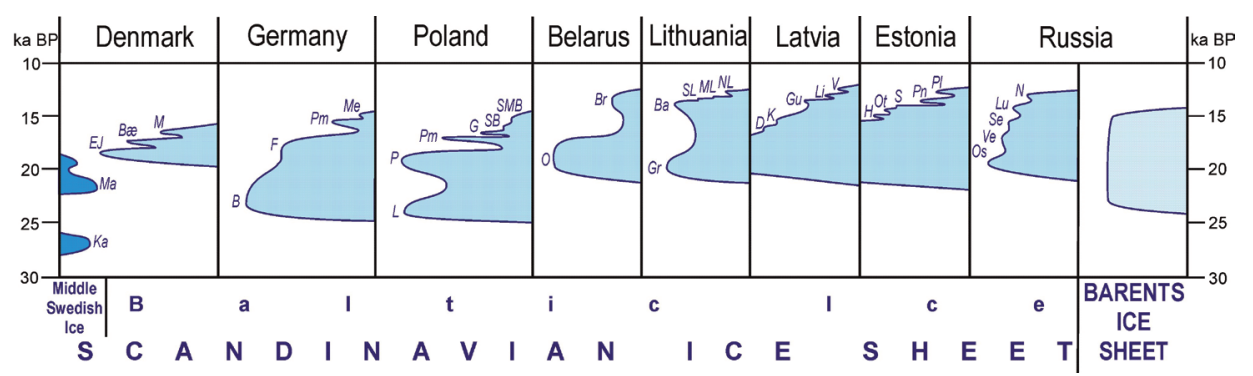

Figure 2. Time-distance diagram of Late Weichselian margin of the Scandinavian and Barents ice sheets with glacial phases: B - Brandenburg, Ba-Baltija, Ba-Balthav, Br-Braslav, D - Dagda, EJ - East Jylland, F-Frankfurt, G - Gardno, Gr - Grūda, Gu - Gulbene, H - Haanja, K - Kaldabruna, Ka - Kattegat, L-Leszno, Li-Linkuva, Lu - Luga, M-M Ma-Main, Me - Mecklenburg, ML-Middle Lithuanian, N-Neva, NL - North Lithuanian, $O$-Orsha, Os - Ostashkov, Ot - Otepää, P - Poznań, Pl-Palivere, Pm-Pomeranian, $P n$-Pandivere, S - Sakala, SB - Stupsk Bank, Se - Sebezha, SL-South Lithuanian, $S M B$ - Southern Middle Bank, V-Valdemärpils, Ve-Vepsian; distances are not in scale.

\subsection{Estonia}

The beginning of the Late Weichselian glaciation of Estonia was estimated for around $22 \mathrm{ka} \mathrm{BP}$ and the ice sheet advanced from the northwest, passing across the country and reaching its maximum position in the territory of Russia (Kalm et al., 2011). Five major ice-marginal zones were distinguished in Estonia (Fig. 1, Table 1) including Haanja ( 14.9 cal kyrs BP), Otepää (14.3-14.2 cal kyrs BP), Sakala (14.1-14.0 cal kyrs BP), Pandivere (13.9-13.7 cal kyrs BP) and Palivere (12.7 cal kyrs BP). They were formed during ice decay because of stillstands and readvances of the ice sheet margin (Fig. 2). Several Late Weichselian ice streams and lobes were reflected by a pattern of glacial landforms all over the country.

\subsection{Russia}

There were many gaps in recognition of the Late Weichselian ice-marginal formations in Russia (cf. Kalm, 2012). Except from the European north, there were only a few recent publications on glacial landforms in this area and the chronological data were 
extremely rare. For the Kaliningrad District of Russia in the far west there was a single regional geological monograph available only (Dodonov et al., 1976), but it presented neither deglaciation limits nor correlation with the neighboring countries. However, it seemed probable that two post-Pomeranian glacial phases had their limits in the Kaliningrad District (Fig. 1). A little more information was known for the area to the east of the Baltic States. The outermost ice sheet limit during the Ostashkov phase (cf. Kalm, 2012) was marked by a system of pronounced ice-marginal landforms (end moraines and hummocky landscapes with frequent lakes). They ran across the northwestern Russian Plain from the Valdai Upland in the south to the Vaga and Severnaya Dvina river valleys in the north. To the north, the ice sheet occupied the lower reaches of the Mezen River and it ran along the western shore of the Kanin Peninsula. The maximum position of the ice sheet advance was attained around 20-18 ka BP on the northwestern Russian Plain and around 17-15 ka BP in the Arkhangelsk area (Svendsen et al., 2004). Considerably much less was known about the deglacial history, although several ice sheet limits were indicated locally (Svendsen et al., 2004; Kalm, 2012), among them in turn (Fig. 2; Table 1): Vepsian (presumably corresponding to the Pomeranian phase in central Europe), Sebezha, Luga (14.2 cal kyrs BP) and Neva (13 cal kyrs BP).

The Scandinavian Ice Sheet coalesced with the Barents Ice Sheet (BIS) near the northern tip of the Kanin Peninsula (Fig. 1). The BIS was very limited in that time and its marginal formations at southern and eastern flanks occurred on the present seafloor in the southeastern Barents Sea to the south of the Kolguyev Island (Astakhov, 2011). The ice sheet reached the northern shelf break as early as $23 \mathrm{ka} \mathrm{BP}$ and started to recede from the shelf margin at around $15 \mathrm{ka} \mathrm{BP}$ (Svendsen et al., 2004).

\section{Discussion and conclusions}

During the Late Weichselian most northern continental Europe was occupied by the Scandinavian Ice Sheet. Only a small, north-easternmost fragment of this area has developed under the influence of the Barents Ice Sheet that occupied the Barents Sea shelf. The main ice sheet limits were not synchronous in northern continental Europe during the Late Weichselian and detailed correlations of their ice-marginal formations were not fully possible yet. Numerous ice sheet limits have not been dated by radiometric methods or their ages were not consistent occasionally with one another and these discrepancies were only partly due to different dating methods used. It is quite clear at present that the depression of the Baltic Sea played a decisive role in controlling the ice-movement directions. There is also a general agreement that the Late Weichselian maximum ice sheet limit in southern and southeastern sectors of SIS was time-transgressive and the same seems obvious for most younger deglacial limits. Such pattern was basically due to different ice movement directions within SIS, both in the very west (Middle Swedish ice) and in the east.

During the initial part of the Late Weichselian glaciation, the SIS reached northern continental Europe straight from the northeast or north to Denmark, Germany and western Poland (Fig. 1). Presumably in the same time the ice moved along the Baltic Sea depression but due to longer distance, it reached considerably later central and mid- 
eastern Europe, coming from the east and northeast. Eastern Europe, including Estonia and Russia was reached by SIS from the north and northwest.

The maximum ice sheet limit during the Late Weichselian (at present roughly connected with the LGM -for discussion see Clark et al., 2009) in northern continental Europe corresponded to the Main ice advance in Denmark, the Brandenburg phase in Germany and the Leszno phase in western Poland. It was represented by a younger glacial phase further to the east: the Poznań phase in central and eastern Poland, the Orsha phase in Belarus, the Grūda phase in Lithuania and the Ostashkov phase in Russia (Fig. 2). Thus, the maximum ice sheet limit occurred at 24-17 cal kyrs BP: it was younger in Denmark, older in Germany and western Poland, younger to the east of the Middle Vistula valley and older again at the Barents Sea shelf. Age differences could be also noted for the younger deglacial phases. They were only partly due to lobate patterns of marginal formations that reflected not only paleo-ice streams in the ice sheet body but also varying dynamics of SIS and BIS or inside each of them. The other reason for ice sheet limit diversified age within each of the successive terminal zones were varying distances from the ice sheet divide in Scandinavia. Regional differences in ice sheet margins could result also from varying thickness of Quaternary deposits in the formerly glaciated area of northern continental Europe (cf. Gorlach et al., 2014).

The maximum limit has been commonly considered for a synchronic one, in western part of central Europe, with the Brandenburg phase in Germany and Leszno phase in Poland. In central and eastern Poland the younger Poznań phase (equivalent to the Frankfurt phase in Germany) had been considered occasionally as the most extensive but this idea has been undoubtedly proved recently (Molewski, 2007; Wysota et al., 2009; cf. Marks, 2012). The presented compilation of ice sheet limits and combined with their ages has built framework for a new chronological scheme of the Late Weichselian deglacial phases for SIS in northern continental Europe.

During the Late Weichselian deglaciation there were numerous readvances (preceded by recessions) and standstills of the ice sheet margin (Fig. 2). Such readvances were stated for all ice sheet limits in Denmark (Houmark-Nielsen, 2011), Pomeranian and Mecklenburg phases in Germany (Ehlers et al., 2011), Poznań, Pomeranian and Gardno phases in Poland (Marks, 2012), Baltija and North Lithuanian phases in Lithuania (Guobyte, Satkunas, 2011)), Linkuva phase in Latvia (Zelčs et al., 2011) as well as Otepää, Pandivere and Palivere phases in Estonia (Kalm et al., 2011). Even the ice sheet margins that were considered isochronous, could behave differently in the neighboring regions. A reason for that was not only the diversified dynamics of the ice sheet body but also possible incorrect correlation of ice-marginal formations, their wrong genetic classification and insufficient knowledge of regional Quaternary geology.

\section{Acknowledgements}

Valuable comments of two anonymous reviewers were of great help in improving the manuscript. 


\section{References}

Astakhov, V. 2011. Ice margins of northern Russia revisited. In J. Ehlers, P.L. Gibbard, P.D. Hughes (eds.), Quaternary Glaciations - Extent and Chronology, a closer look. Developments in Quaternary Science 15, 323-336. Elsevier, The Netherlands.

Ber, A. 2002. O zasięgu zlodowacenia Wisły w Polsce północno-wschodniej na podstawie badań geomorfologicznych i termoluminescencyjnych; w odpowiedzi Henrykowi Banaszukowi. Przegląd Geograficzny 74 (2), 243-247.

Bitinas, A. 2012. New insights into the last deglaciation of the southeastern flank of the Scandinavian Ice Sheet. Quaternary Science Reviews 44, 69-80.

Boulton, G.S., Dongelmans, P., Punkari, M., Broadgate, M. 2004. Evidence of European ice sheet fluctuation during the last glacial cycle. In Ehlers, J., Gibbard, P.L. (eds.), Quaternary Glaciations - Extent and Chronology 1: Europe. Elsevier, Amsterdam, pp. 441-460.

Clark, P.U., Dyke, A.S., Shakun, J.D., Carlson, A.E., Clark, J., Wohlfarth, B., Mitrovica, J.X., Hostetler, S.W., McCabe, A.M. 2009, The Last Glacial Maximum. Science 325, 710-714.

Dodonov, A.E., Namiestnikov, Y.G., Yakushova, A.F. 1976. Novieysha tektonika yugo-vostochnoi chasti baltiyskoi sineklizy. Izdatelstvo Moskovskogo Universiteta, Moskva.

Dzierżek, J., Zreda, M. 2007. Timing and style of deglaciation of northeastern Poland from cosmogenic ${ }^{36} \mathrm{Cl}$ dating of glacial and glaciofluvial deposits. Geological Quarterly 51 (2), 203-216.

Ehlers, J., Gibbard, P.L. (eds.) 2004. Quaternary Glaciations - Extent and Chronology, part 1: Europe. Elsevier, Amsterdam, 475 pp.

Ehlers, J., Grube, A., Stephan, H.J., Wansa, S. 2011. Pleistocene Glaciations of North Germany new results. In J. Ehlers, P.L. Gibbard, P.D. Hughes (eds.), Quaternary Glaciations - Extent and Chronology, a closer look. Developments in Quaternary Science 15, 149-162. Elsevier, The Netherlands.

Gorlach, A., Kalm, V., Hang, T. 2014. Thickness distribution of Quaternary deposits in the formerly glaciated part of the East European Plain. Journal of Maps, doi.org/10.1080/174 45647.2014.9546646.

Guobytè, R. 2004. A brief outline of the Quaternary of Lithuania and the history of its investigation. In Ehlers, J., Gibbard, P.L. (eds.), Quaternary Glaciations - Extents and Chronology 1: Europe. Elsevier, Amsterdam, pp. 245-250.

Guobytė, R., Satkūnas, J. 2011. Pleistocene glaciations in Lithuania. In J. Ehlers, P.L. Gibbard, P.D. Hughes (eds.), Quaternary Glaciations - Extent and Chronology, a closer look. Developments in Quaternary Science 15, 231-246. Elsevier, The Netherlands.

Heine, K., Reuther, A.U., Thieke, H.U., Schulz, R., Schlaak, N., Kubik, P.W. 2009. Timing of Weichselian ice marginal positions in Brandenburg (northeastern Germany) using cosmogenic in situ ${ }^{10} \mathrm{Be}$. Zeitschrift für Geomorphologie NF 53 (4), 433-454.

Houmark-Nielsen, M. 2008. Testing OSL failures against regional Weichselian glaciation chronology from southern Scandinavia. Boreas 37, 660-677.

Houmark-Nielsen, M. 2011. Pleistocene glaciations in Denmark: a closer look at chronology, ice dynamics and landforms. In J. Ehlers, P.L. Gibbard, P.D. Hughes (eds.), Quaternary Glaciations - Extent and Chronology, a closer look. Developments in Quaternary Science 15, 47-58. Elsevier, The Netherlands.

Houmark-Nielsen, M., Linge, H., Fabel, D., Schnabel, C., Xu, S., Wilcken, K.M., Binnie, S. 2012. Cosmogenic surface exposure dating the last deglaciation in Denmark: discrepancies with independent age constraints suggest delayed periglacial landform stabilisation. Quaternary Geochronology 13, 1-17. 
Houmark-Nielsen, M., Kjær, K.H. 2003. Southwest Scandinavia, 40-15 kyr BP: palaeogeography and environmental change. Journal of Quaternary Science 18 (8), 769-786.

Kalm, V., Raukas, A., Rattas, M., Lasberg, K. 2011. Pleistocene glaciations in Estonia. In J. Ehlers, P.L. Gibbard, P.D. Hughes (eds.), Quaternary Glaciations - Extent and Chronology, a closer look. Developments in Quaternary Science 15, 95-104. Elsevier, The Netherlands.

Kalm, V. 2012. Ice-flow pattern and extent of the last Scandinavian Ice Sheet southeast of the Baltic Sea. Quaternary Science Reviews 44, 51-59.

Karabanov, A.K., Matveyev, A.V. 2011. The Pleistocene glaciations in Belarus. In J. Ehlers, P.L. Gibbard, P.D. Hughes (eds.), Quaternary Glaciations - Extent and Chronology, a closer look. Developments in Quaternary Science 15, 29-35. Elsevier, The Netherlands.

Keilhack, K. 1899. Die Stillstandslagen des letzten Inlandeises und die hydrographische Entwicklung des pommerschen Küstengebietes. Jahrbuch der Preussischen Geologischen Landesanstalt 19, 90-152.

Kliewe, K. 1961. Vergleichende Betrachtungen zur glaziären Genese der Odramündungsinseln. Geographische Berichte 20/21 (3/4), 232-240.

Kozarski, S. 1995. Deglaciation of northwestern Poland: environmental conditions and geosystem transformation ( 20 ka - 10 ka BP). Dokumentacja Geograficzna 1, 1-82.

Lambeck, K., Purcell, A., Zhao, J., Svensson, N.O. 2010. The Scandinavian Ice Sheet: from MIS 4 to the end of the Last Glacial Maximum. Boreas 39 (2), 410-435.

Lencewicz, S. 1927. Glaciation et morphologie du Bassin de la Vistule Moyenne. Prace Państwowego Instytutu Geologicznego 2, 1-220.

Lewiński, J., Łuniewski, A., Małkowski, S., Samsonowicz, J. 1927. Przewodnik geologiczny po Warszawie i okolicy. Wydawnictwo Oddziału Warszawskiego Komisji Fizjograficznej Polskiej Akademii Umiejętności, Warszawa, 1-178.

Liedke, H., 1981. Die Nordischen Vereisungen Mitteleuropas 1:1 000 000. Paulinus, Trier.

Litt T., Behre, K.-E., Meyer, K.-D., Stephan, H.-J., Wansa, S., 2007. Stratigraphical terms for the Quaternary of the North German glaciation area. In Litt, T. (ed.), Stratigraphie von Deutschland - Quartär. Quaternary Science Journal 56 (1/2), 7-65.

Lüthgens, C., Böse, M. 2011. Chronology of Weichselian main ice marginal positions in northeast Germany. Quaternary Science Journal 60 (2-3), 236-247.

Lüthgens, C., Böse, M., Krbetschek, M. 2010. On the age of the young morainic morphology in the area ascribed to the maximum extent of the Weichselian glaciation in north-eastern Germany. Quaternary International 222, 72-79.

Marks, L., 2002. Last Glacial Maximum in Poland. Quaternary Science Reviews 21, 103-110.

Marks, L. 2011. Quaternary Glaciations in Poland. In J. Ehlers, P.L. Gibbard, P.D. Hughes (eds.), Quaternary Glaciations - Extent and Chronology, a closer look. Developments in Quaternary Science 15, 299-303. Elsevier, The Netherlands.

Marks, L. 2012. Timing of the Late Vistulian (Weichselian) glacial phases in Poland. Quaternary Science Reviews 44, 81-88.

Marks, L., Ber, A., Gogołek, W., Piotrowska, K. (eds.) 2006. Geological map of Poland 1:500 000, with explanatory text. Państwowy Instytut Geologiczny, Warszawa.

Mojski, J.E. 1992. Vistulian stratigraphy and TL dates in Poland. Sveriges Geologiska Undersökning 81, 195-200.

Molewski, P. 2007. Neotectonic and glacidynamic conditions for the formation of the Pleistocene of the Kujawy Moraine Plateau. Wydawnictwo Naukowe Uniwersytetu Mikołaja Kopernika, Toruń, 1-140.

Punkari, M. 1997. Glacial and glaciofluvial deposits in the interlobate areas of the Scandinavian Ice Sheet. Quaternary Science Reviews 16, 741-753. 
Raukas, A., Stankowski, W. 2005. Influence of sedimentological composition on OSL dating of glaciofluvial deposits: examples from Estonia. Geological Quarterly 49 (4), 463-470.

Reimer, P.J., Baillie, M.G.L., Bard, E., Bayliss, A., Beck, J.W., Blackwell, P.G., Bronk Ramsey, C., Buck, C.E., Burr, G.S., Edwards, R.L., Friedrich, M., Grootes, P.M., Guilderson, T.P., Hajdas, I., Heaton, T.J., Hogg, A.G., Hughen, K.A., Kaiser K.F., Kromer, B., McCormac, F.G., Manning, S.W., Ramsey, C.B., Reimer, R.W., Richards, D.A., Southon, J.R., Talamo, S., Turney, C.S.M., Van der Plicht, J., Weyhenmeyer, C.E. 2009. IntCal09 and marine09 radiocarbon age calibration curves, 0-50,000 years cal BP. Radiocarbon 51 (4), 1111-1150.

Rinterknecht, V.R., Bitinas, A., Clark, P.U., Raisbeck, G.M., Yiou, F., Brook, E.J. 2008. Timing of the last deglaciation in Lithuania. Boreas 37, 426-433.

Rinterknecht, V., Braucher, R., Böse, M., Bourlès, D., Mercier, J.-L. 2012. Late Quaternary ice sheet extents in northeastern Germany inferred from surface exposure dating. Quaternary Science Reviews 44, 89-95.

Rinterknecht, V.R., Clark, P.U., Raisbeck, G.M., Yiou, F., Bitinas, A., Brook, E.J., Marks, L., Zelčs, V., Lunkka, J.-P., Pavlovskaya, I.E., Piotrowski, J.A., Raukas, A. 2006a. The last deglaciation of the southeastern sector of Scandinavian Ice Sheet. Science 311, 1449-1452.

Rinterknecht, V.R., Marks, L., Piotrowski, J.A., Raisbeck, G.M., Yiou, F., Brook, E.J., Clark, P.U. 2005. Cosmogenic ${ }^{10} \mathrm{Be}$ ages on the Pomeranian Moraine, Poland. Boreas 34 (2), 186-191.

Rinterknecht, V.R., Marks, L., Piotrowski, J.A., Raisbeck, G.M., Yiou, F., Brook, E.J., Clark, P.U. 2006b. 'Cosmogenic dating of the Pomeranian Moraine: adding a regional perspective': Reply to comments. Boreas 35 (3), 605-606.

Rinterknecht, V.R., Pavlovskaya, I.E., Clark, P.U., Raisbeck, G.M., Yiou, F., Brook, E.J. 2007. Timing of the last deglaciation in Belarus. Boreas 36 (3), 307-313.

Stankowski, W., Bluszcz, A., Nita, M. 1999. Stanowiska osadów górnoczwartorzędowych Mikorzyn i Sławoszewek w świetle badań geologicznych datowania radiowęglowego i luminescencyjnego oraz analiz palinologicznych. In A. Pazdur, A. Bluszcz, W. Stankowski, L. Starkel (eds), Geochronologia górnego czwartorzędu Polski. Politechnika Śląska, Gliwice, 87-110.

Stephan, H.-J. 2001. The Young Baltic advance in the western Baltic depression. Geological Quarterly 45 (4), 359-363.

Svendsen, J.I., Alexanderson, H., Astakhov, V.I., Demidov, I., Dowdeswell, J.A., Funder, S., Gataullin, V., Henriksen, M., Hjort, C., Houmark-Nielsen, M., Hubberten, H.W., Ingólfsson, Ó., Jakobsson, M., Kjær, K.H., Larsen, E., Lokrantz, H., Lunkka, J-P., Lyså, A., Mangerud, J., Matiouchkov, A., Murray, A., Möller, P., Niessen, F., Nikolskaya, O., Polyak, L., Saarnisto, M., Siegert, C., Siegert, M.J., Spielhagen, R.F., Stein, R. 2004. Late Quaternary ice sheet history of northern Eurasia. Quaternary Science Reviews 23, 1229-1271.

Uścinowicz, S. 1999. Southern Baltic area during the last glaciation. Geological Quarterly 43 (2), 137-148.

Velichko, A.A., Faustova, M.A., Pisareva, V.V., Gribchenko, Yu.N., Sudakova, N.G., Lavrentiev, N.V. 2011. Glaciations of the East European Plain: distribution and chronology. In J. Ehlers, P.L. Gibbard, P.D. Hughes (eds.), Quaternary Glaciations - Extent and Chronology, a closer look. Developments in Quaternary Science 15, 337-359. Elsevier, The Netherlands.

Woldstedt, P. 1925. Die grossen Endmoränenzüge Norddeutschlands. Zeitschrift für Deutschen Geologischen Gesellschaft 77, 172-184.

Woldstedt, P. 1931. Über Randlagen der letzten Vereisung in Ostdeutschland und Polen und über die Herausbildung des Netze-Warthe Urstromtales. Jahrbuch der Preussischen Geologischen Landesanstalt 52, 59-67. 
Wysota, W., Molewski, P., Sokołowski, R.J. 2009. Record of the Vistula ice lobe advances in the Late Weichselian glacial sequence in north-central Poland. Quaternary International 207 (1-2), 26-41.

Zelčs, V., Markots, A., Nartišs, M., Saks, T. 2011. Pleistocene glaciations in Latvia. In J. Ehlers, P.L. Gibbard, P.D. Hughes (eds.), Quaternary Glaciations - Extent and Chronology, a closer look. Developments in Quaternary Science 15, 221-229. Elsevier, The Netherlands. 